53 | P a g e | Bubble Network System and Achievement Motivation Toward Students' Writing Achievement

\title{
Bubble Network System and Achievement Motivation Toward Students' Writing Achievement
}

\author{
By: \\ Suparman, H Lalu
}

\begin{abstract}
The investigated of this study was the effect of BNS (Bubble Network. System ) strategy and achievement motivation toward students writing achievement at the eleventh graders of Madrasah Aliyah NW Kotaraja. The design of the research was post-test only control group design. The study involved 80 students as samples which were taken by using random sampling technique, where the sample were divided into two groups, experimental and control group. The collection of the data were collected using questionnaire and test, which were analyzed using two-ways ANOVA. The finding data of the study displayed that (1) there is a significant difference on the English writing between the students taught by using BNS strategy and conventional strategy $\left(F_{A}=33.5, p<0.05\right)$, (2) there is a significant interaction between teaching strategy and achievement motivation on the English writing $\left(F_{A B}=30.12, p<0.05\right)$, (3) for the students with high achievement motivation, there is a significant difference on the English writing taught by BNS strategy and conventional strategy $Q_{o b}=10.4$, $p<0.05)$, (4) for the students with low achievement motivation, there is no significant difference on the English writing taught by BNS strategy and conventional strategy $\left(Q_{o b}\right.$ $=0.302, p>0.05$ ).
\end{abstract}

Keywords: BBS strategy, achievement motivation, English writing achievement

\begin{abstract}
ABSTRAK: Penelitian ini mengkaji pengaruh strategy BNS ( Bubble Network System ) dan motivasi berprestasi terhadap prestasi menulis pada siswa semester sebelas Madrasah Aliyah NW Kotaraja. Desain penelitian menggunakan rancangan posttest only control group design. Sampel penelitian berjumlah 80 orang mahasiswa yang diambil menggunakan teknik random sampling, dimana sampel penelitian dibagi kedalam kelompok eksperimen dan kontrol. Data penelitian menggunakan kuisioner dan tes dianalisa menggunakan ANOVA dua jalur. Hasil penelitian mengungkapkan bahwa (1) terdapat perbedaan signifikan prestasi menulis siswa yang mengikuti pembelajaran strategy BNS dan siswa yang mengikuti pembelajaran konvensional $\left(\mathrm{F}_{\mathrm{A}}=33,5, \mathrm{p}<0,05\right)$, (2) terdapat interaksi signifikan antara strategy pembelajaran (strategy BNS dan pembelajaran konvensional) dan motivasi berprestasi terhadap prestasi menulis siswa $\left(\mathrm{F}_{\mathrm{AB}}=30,12, \mathrm{p}<0,05\right)$, (3) terhadap siswa yang memiliki motivasi berprestasi tinggi, terdapat perbedaan signifikan prestasi menulis siswa yang mengikuti pembelajaran menggunakan strategy BNS dan siswa yang mengikuti pembelajaran konvensional $\left(\mathrm{Q}_{\text {hitung }}=10,4, \mathrm{p}<0,05\right)$, (4) terhadap siswa yang memiliki motivasi berprestasi rendah, tidak terdapat perbedaan signifikan prestasi menulis siswa yang mengikuti pembelajaran menggunakan strategy BNS
\end{abstract}


54 | P a g e | Bubble Network System and Achievement Motivation Toward Students' Writing Achievement

dan mahasiswa yang mengikuti pembelajaran konvensional $\left(\mathrm{Q}_{\text {hitung }}=\right.$ 0,302, p > 0,05).

Kata kunci: strategy BNS, motivasi berprestasi, kemampuan menulis bahasa Inggris

\section{INTRODUCTION}

English as an international language is mostly used in all countries around the world. It is used in almost every aspect of life, such as in science, technology, business, politics, education, tourism, entertainment and international relationship. In Indonesia, English itself has been taught from the elementary school level, up to the university level. And even now, it has been taught in kindergarten level as well.

One of the main necessities in learning English subject is the development of the four basic skills of language, which are listening, speaking, reading and writing. From the four skills, writing is the most complex one to master. Writing is the most efficiently acquired when practice in writing parallels with practice in the other skills. Writing provides an excellent consolidating activity. Writing is also useful to provide exercises in the form of texts. It has been suggested that writing is regarded as a service activity for most students rather than an end in itself; the teacher will find that the problem of 'how much writing?' soon solves itself. The type of writing in which the students are engaged will become more sophisticated as they acquire greater facility in the exercise of the other skills.

Weigle (2002, p.11) points out that writing which was once considered the domains of the elite and well educated has become an essential tool for people of all walks of life in today's global community. Furthermore, it is now widely recognized that writing plays a vital role not only in conveying information, but also in transforming knowledge to create new one. In writing, the writers inform us an idea, message and the written form. They can understand experience, event, history and idea easily. However, knowledge and experience are significantly needed. Without having good knowledge in writing, the writers will not be able to convey their ideas to the readers. 
55 | P a g e | Bubble Network System and Achievement Motivation Toward Students' Writing Achievement

In Indonesia the implemented curriculum is SBC (School Based Curriculum ) of senior high school eleventh grade semester two states that standard competency of writing that will be achieved, "Express the meaning in short functional text and essay of narrative, spoof and hortatory in daily life context ". It means the students should learn and mastered in writing and they are hoped to be able to write an essay based on the genres that are taught in writing by the teacher. Besides that, the students should know the purpose of each essay that they are learned, whereas each text has different purpose.

However, based on the researcher pre observation, it was found that the eleventh graders of $M A N W$ Kotaraja still found a lot of difficulties in developing their ability in writing essay in the form of monolog text. They thought that writing skill was very difficult to learn, whereas they should write their ideas with rhetorical structure, language features and related vocabulary that are not easy to do in the short time. Even, some other students did the cheating because they had no ideas for their writing. For instance, when the teacher taught and asked them to make narrative essay as their assignment based on their own story and sentences, they did not do it. However, they just took the text from internet or others English books and rewrite it in their task paper. Furthermore, if this condition still continues, the gaining basic competency of writing will never achieved.

Based on the real condition above, it could be seen that the students of $M A$ NW KOTARAJA faced many difficulties in writing because of two problems. First, the students were not able to write a good essay because they had no ideas or fewer ideas with their writing. So, it was difficult for them to start, arrange and organize their paragraphs into good essay, so that they did not write their essay well.

The second problem of writing was dealing with the teacher's strategy. The teachers often used the same strategy like asking the students to listen to the teacher's explanation and asking them to write their essay directly. The teachers rarely implemented other strategy to create and to increase students' passion while writing. So, it made the students feel bored, and hard in writing their essay.

In brief, the teachers had to find another strategy which was suitable with the student's need to make writing teaching learning process become more interesting and to decrease students' difficulty in writing. In addition, for developing student's 
56 | P a g e | Bubble Network System and Achievement Motivation Toward Students' Writing Achievement

ability in writing, the strategy in learning process is very important. Because by taking an appropriate strategy, the teacher can help students begin to develop students' writing ability.

Therefore Bubble network system is one of the techniques which can be implemented in writing to develop students' ability especially in writing narrative text. Then, this technique will give good impact for learners in teaching learning process especially in writing. Using bubble network system facilitates the teaching of writing to the students because it is not only helps the teacher to connect materials but it also motivate the students to write easily and creatively.

Bubble network system technique goes to many names, it is same with clustering, bubbling, webbing, diagramming or mapping of words. They are all same thing. They all mean putting our ideas in circle and drawing lines between them to make connections. This technique was devolved by Rico (1983) to improve writing skill is adapted by Henry $(1985$; 1986) to facilitate classroom setting in (http://Sekolah-menulis $\backslash$.com/blog/penulisan/mengatasi-hambatan-menulis).

Walton Burns (2014) in (http://www.englishadvantage.info/lesson/prewriting-techniques/) said that a bubble network system is the same thing as a bubble chart. It's a way of organizing ideas or brainstorming before writing. Students can write the topic or theme of the essay in the middle of a piece of paper and then circle it. Then they write ideas or things related to that topic around it and circle those and draw lines connecting them to the central topic. Then students can think of words related to these subtopics and write those around each one as they write more and more they will see connections between ideas. Then students can go through and pick the best topics and subtopics for their essay.

Bubble network system like listing another way to get ideas to write about something and write them in circle or bubbles, around the topic (Hogue 1999). Based on this statement, bubble network system is the writing technique to develop their ideas (learners) and write the words or phrases in circles or bubbles.

According to Meade (2010) bubble network system is a powerful tool because it taps into the right brain, which drives creativity. Our right brain is where fresh ideas and original insights are generated. The left brain, in contrast, is more logical and orderly. A good piece of writing requires that both brains work together, 
57 | P a g e | Bubble Network System and Achievement Motivation Toward Students' Writing Achievement

but if your left brain is too dominant when you start a piece, it inhibits the free flow of thought. It muffles the left brain for a time so the right brain can play freely. A type of brainstorming, bubble network system brings our hidden thoughts to the surface. The bubble network system or clustering or mapping can help you become aware of different ways to think about a subject. The bubble network system or cluster or map combines the two stages of brainstorming (recording ideas and then grouping them) into one. It also allows you to see, at a glance, the aspects of the subject about which you have the most to say, so it can help you choose how to focus a broad subject for writing. It involves constructing hierarchy of ideas instead of pure random association.

Scholes (1989) adds that clustering, or grouping ideas is a good way for writers who think spatially. In addition to illustration using circles and lines, writers can also construct clusters with either tree diagrams or balloons and strings.

Through clustering words in the bubble network system, we can see how the ideas are related to each other (Barbara, 2004, p.22), because it is one of the techniques of powerful ideas generation besides free-writing, questioning, and making a list. The bubble network system can be used not only to organize, but also to generate ideas. It is done quickly and can be messy, so field independent, more linear thinkers are often uncomfortable with the process. For them, an outline remains the preferred method of organizing ideas. On the other hand, field sensitive learners enjoy the freedom they have to use the clustering process in a variety of ways (Dickinson, 2001)

According to Gabriel (1983) states that bubble network system is a nonlinear activity that generates ideas, images and feelings around a stimulus word. As students cluster, their thoughts tumble out, enlarging their word bank for writing and often enabling them to see patterns in their ideas. It is a generative, open-ended, nonlinear, visual structuring of ideas, events, and feelings. It is a way of mapping an interior landscape as it begins to emerge. Moreover, it is one of the most valuable pre-writing activities to create patterns, build connection, and establish associations between the students' own experience and new information, between known facts and new concepts, between parts of concepts or problems and its whole.

To get started, write a word or phrase in the middle of a page and draw a 
58 | P a g e | Bubble Network System and Achievement Motivation Toward Students' Writing Achievement

circle around it. As students' mind starts to make associations, write the word next to the first word, draw a circle around it, and then draw a straight line between the two circles to connect them. As more ideas come to them, continue drawing lines and circles to show their relationship to each other, Dankers (2006).

Tomlinson (1998) adds that bubble network system is a pre-writing activity in which the writer is free to associate strings of ideas around word or idea. It means that the students may use pre-writing activities whenever they need them to get difficulties in generating some ideas and writing again. Furthermore, some prewriting activities are designed to make students' ideas flow easily. Some reveal what really feel about a subject or what is bothering us about a situation. Still others are designed to help us focus a topic or organize it. From the explanation above, it is clear that when students are searching for ideas for writing assignments, projects, or presentation, often they need a spark to make ideas begin to flow. That's where idea maps come in. this visual learning technique stimulates students to generate ideas, follow them through and develop their thoughts visually. Idea maps help students brainstorm, solve problems and plan their work. Using fast, five minutes exercises in word and idea association, idea maps connect keywords, symbols, colors, and graphics to form nonlinear networks of potential ideas and thoughts.

Another factor that significantly influences in foreign language teaching is the students' achievement motivation. Students' success of learning English cannot be separated from their achievement motivation. If the students have high achievement motivation in learning, they will do more learning activity. For the lecturers, knowing students' achievement motivation has a very important role to ask students gaining success in learning a foreign language. It is an urgent variable to be considered by English Foreign Language teacher in recognizing the students' problem and to create conducive atmosphere in the classroom that will drive the students to do more toward learning English. In corellation, Zenzen (2002) defines achievement motivation as the need to perform well, strives for success, and proved by persistence and effort in the face of difficult. Students who have high achievement motivation are hard workers that always do their best performance to achieve something in their lives. Furthermore, Locke and Latham (1994) in Marhaeni, (2005) emphasize three motives why students have achievement motivation. Those motives 
59 | P a g e | Bubble Network System and Achievement Motivation Toward Students' Writing Achievement

are called Goal Theory. This theory divides the human motives into three such as: 1) mastery goals which (also called learning goals) focus on gaining competence or mastering a new set of knowledge or skills, 2) performance/normative goals (also called ego-involvement goals) which focus on achieving normative-based standards, doing better than others, or doing well without a lot of effort, and 3) social goals which focus on relationship among people. Based on this goal theory, it can be summed up that students' achieving the tasks are strongly influenced by their need to achieve and a fear of failure. If a student is engaged to achieve, his/her effort is dominantly supported by positive responsibility. In contrast, if a student is motivated to be failure his/her activities are rarely to appear positive responsibility. Related to second language acquisition, an English Foreign Language learner is going to find a task of English easily if she/he has high achievement to be success. Meanwhile an English Foreign Language learner who has low achievement she/he will find the difficulties in completing the task given. More than that Schunk (2008), in Marhaeni (2005) discloses four general types of students toward achievement motivation: 1 ) the success-oriented student who is high in motive for success and low in fear of failure is highly engaged in achievement activities and not anxious or worried by performance, 2) failure avoider which the opposite of success-oriented student. Failure avoider student who is high in fear of failure and low in motive for success, which is anxious and attempts to avoid failure by procrastinating and using other self-handicapping strategies. This type of student would be reluctant to engage in academic comprehension work, 3) over strivers are students who are high in both motives; they try to approach success but simultaneously fear failure greatly. These students work hard at comprehension tasks but also feel anxious and stressed because of their fear of failure, and 4) failure accepters' students who almost do well in class, but are constantly asking the teacher about their grades and show signs of anxiety and worry about doing well. Realizing the role of achievement motivation described above, the researcher affirm that students' achievement motivation is important to be investigated. Therefore, achievement motivation to be a moderator variable in this study. The consideration is that achievement motivations encourage the students to do more writing short monolog text in English, which will support them in acquiring good achievement for their writing achievement. Addressing BNS 
60 | P a g e | Bubble Network System and Achievement Motivation Toward Students' Writing Achievement

strategy and students' achievement motivation in learning English, the study tried to disclose four questions, namely: (1) whether there is a significant difference in writing achievement between students who are taught by using BNS strategy and those taught by using the conventional strategy; (2) whether there is a significant interactional effect between the learning strategies applied and achievement motivation toward students' writing achievement; (3) whether there is a significant difference in writing achievement between students with high achievement motivation who are taught by using BNS strategy and those taught by using the conventional strategy; and (4) whether there is a significant difference in writing achievement between students with low achievement motivation who are taught by using BNS strategy and those taught by using the conventional strategy. The study aimed at (1) finding out whether there is a significant difference in writing achievement between college students who are taught by using BNS strategy and those taught by using the conventional strategy; (2) finding out whether there is a significant interactional effect between teaching strategies applied and students' achievement motivation toward writing achievement; (3) finding out whether there is a significant difference in writing achievement between students who had high achievement motivation taught by using BNS strategy and those taught by using the conventional strategy; and (4) finding out whether there is a significant difference in writing achievement between students with low achievement motivation who are taught by using BNS strategy and those taught by using the conventional strategy.

\section{METHODS}

\section{Research Design}

This research was designed in an experimental design called Posttest Only Control Group Design using 2x2 factorial arrangement. One group treated the experimental treatment (taught by using BNS strategy) while other did not, or treated a different treatment (taught by conventional strategy). This study used $2 \times 2$ factorial arrangement. There were three variables in this study, namely: independent, moderator, and dependent variable. The independent variable of this study was BNS strategy and moderator variable was achievement motivation level (high and low). 
$61 \mid$ P a g e | Bubble Network System and Achievement Motivation Toward Students' Writing Achievement

On the other side, the students' English writing was categorized as dependent variable.

\section{Research Population (Source of Data)}

This research was done at the eleventh graders students of Madrasah Aliyah Nabdlatul Wathan Kotaraja East Lombok-NTB. The research was started from January 2016 until May 2016. Before determining the sample of this research, statistic analysis for homogeneity test was done. The homogeneity test of the data was the students' English achievement in the eleventh semester out of the school. After the data was homogeneous population, then carried. Simple Random Sampling techniques was simple random sampling, because sampling was taken based on the experimental class, then the raffle (lottery technique) or the experimental class using a table of random numbers or numbers (random number), for each treatment based on initial homogeneity, then using simple random sampling technique. The population was all the eleventh graders, that it was divided into four classes which consisted of 80 students. The research sample were all the students which finally produce four sample classes in which two classes as experimental groups and two classes as control groups.

\section{Data Collection}

There were two collecting data instruments used writing test and achievement motivation questionnaires in studying English. Both instruments had been tried out to ensure their validity and reliability. Data for this study were collected by using test and non-test. Data which were collected by using test is writing achievement data. In collecting this data, the students were assigned to write a short essay upon particular topic. Their writing were then analyzed and score by 
62 | P a g e | Bubble Network System and Achievement Motivation Toward Students' Writing Achievement

three ratters. Then to ensure the reliability of the ratters' score, the interater reliability analysis was conducted for each test.

The second data was collected by using non-test instrument. The data were collected by using the scale of achievement motivation in studying English. The students were given the scale to be responded. Score for each item was then added up to obtain achievement motivation in studying English score of each student.

\section{Homogeneity and Normality of Data}

The data were analyzed by using descriptive statistics and inferential statistics which was done by using two-ways ANOVA and continued by post hoc analysis namely Tukey test. Before analyzing data, the data were tested in order to find out whether it had normal distribution and homogeneity of variant or not. From the test namely the Kolmogorav-Smirnov statistic to investigate the normality, it was found that the data was normal distributed, while Leven's test of equality of Error variance found that the homogeneity of variance data was homogeneous.

\section{FINDING AND DISCUSSION}

The discussion of the findings was divided into six parts; first, to discuss about the significant effect of BNS strategy and conventional strategy on the student's writing achievement. Second, to discuss about the interactional effect of teaching strategy (BNS strategy and conventional strategy) and students achievement motivation on the student's writing achievement. Third, to discuss about the significant difference on the student's writing achievement between the students with achievement motivation taught by using BNS strategy and conventional strategy. Fourth, to discuss about the significant difference between the students with low achievement motivation taught by using BNS strategy and conventional strategy. Fifth, to discuss about the significant difference on the students achievement between the students with high achievement motivation and the students with low achievement motivation taught by using BNS strategy. Sixth, to discuss about the significant difference on students' writing achievement between the students with high achievement motivation and students with low achievement motivation taught by using conventional strategy. 
63 | P a g e | Bubble Network System and Achievement Motivation Toward Students' Writing Achievement

The first finding on the significant effect between the students' English achievement taught by using BNS strategy and conventional strategy, showed the value of $F_{A}$ was 33.5 while $F_{c v}(1 ; 80 ; 0.01)$ was 6.30. Since $F_{A}$ higher than $F c v$, then Ho (1) which stated “there is no significant effect on college students' writing achievement between the students taught by using BNS strategy and conventional strategy", was rejected. It means that H1 (1) which stated "there is a significant difference in college students' writing achievement between taught by using BNS strategy and conventional strategy", was accepted. It can be concluded that there was a significant effect in college students' writing achievement between taught by using BNS strategy and conventional strategy, where the mean score of college students taught by using BNS strategy was 76.7, it was higher than the mean score of college students' writing achievement for students taught by using conventional strategy was 71.45 .

Based on the result of hypothesis testing and the analysis above, it could be interfered generally that the students' writing achievement taught by using BNS strategy was better than those taught by using conventional strategy. The result of that finding indicated that the BNS strategy was superior to conventional strategy in writing class which could improve the college student's English achievement especially in writing skills. This study also supported by the (Meade 2010) bubble network system is a powerful tool because it taps into the right brain, which drives creativity. Our right brain is where fresh ideas and original insights are generated. The left brain, in contrast, is more logical and orderly. A good piece of writing requires that both brains work together

If the senior high school students perceive learning English to be enjoyable and fun, they will be confident enough to share their perspectives and feelings on paper. He found that the experimental group who were taught by using BNS strategy had higher achievement than the control group that was taught by using conventional strategy.

The second finding on the interactional effect of teaching strategy and students achievement motivation on the senior high school student's English 
64 | P a g e | Bubble Network System and Achievement Motivation Toward Students' Writing Achievement

achievement showed the value of $\mathrm{F}_{\mathrm{AB}}$ on interactional effect was 30.12. If $\mathrm{p}$ value is higher than 0.05 ( $\mathrm{p}>0.05)$, it means that Ho is received. If $\mathrm{p}$ value is lower than 0.05 $(\mathrm{p}<0.05)$, it means that Ho is rejected. From the output, it is seen that $\mathrm{F}$ value is 31.14 and $\mathrm{p}=0.000$. it means that there is an interaction between teaching learning and level of achievement motivation that affect the students' achievement, it means that the null hypothesis Ho (2) which stated "there is no significant interactional effect between teaching strategy ( BNS strategy and conventional strategy) and the students' achievement motivation towards the writing achievement", was rejected. It means that the alternative hypothesis H1 (2) which stated "there is a significant interactional effect between teaching strategy ( BNS strategy and conventional strategy) and students' achievement motivation towards the students' writing achievement", was accepted. So it can be concluded that there is a significant interactional effect between teaching strategy ( BNS strategy and conventional strategy) and students' achievement motivation towards the students' writing achievement.

The interactional effect means that the students with high achievement motivation was best taught by using BNS strategy because the students' writing achievement with high achievement motivation taught by using BNS strategy ( $\overline{\mathrm{X}}$ $=81.50)$ was higher than the students' writing achievement with high achievement motivation taught by using conventional strategy $(\overline{\mathrm{X}}=71.18)$. The same thing happened to the group of students with low achievement motivation. The students' writing achievement with low achievement motivation taught by using BNS strategy ( $\overline{\mathrm{X}}=72.00$ ) was higher than the students' writing achievement (Y) with low achievement motivation taught by using conventional strategy $(\bar{X}=71.73)$.

On the other hand, the students with low achievement motivation are not challenged by the process of learning. They ignored the process of learning use they were not motivated to do something based on personal satisfaction, but by the product of something. In writing class for example, they do not have their best effort to follow the steps of writing process activity, they were unmotivated to learn. 
65 | P a g e | Bubble Network System and Achievement Motivation Toward Students' Writing Achievement

Therefore, the conventional strategy is very ineffective to be implemented if the students were low achievement motivation. Instead, the BNS strategy was more effective to be implemented because BNS strategy gives chance to make joyful atmosphere of learning that can give a good chance to the students low achievement motivation to learn more. The result of the interview showed that students with low achievement motivation were more interested to be taught by using BNS strategy. This strategy was more interesting to them because they have time to share their ideas freely with their peers and they had chance to look at the progression of information or ideas in their writing to form coherent writing. It also can help the students in composing and revising their writing to produce writing that is coherent.

This supported the findings that students with low achievement motivation taught by using BNS strategy performed better than the students with low achievement motivation taught by using conventional strategy. The power of BNS strategy was very effective for students with high achievement motivation in order to reach their best result. The characteristics of BNS strategy have challenged the fullest potential of students with high achievement motivation to do their best. Considering the characteristics of the BNS strategy and the students with high achievement motivation that has been explained above, we can conclude that the combination of BNS strategy and the achievement motivation resulted in a high writing achievement.

In addition, the students who have high achievement motivation, in BNS strategy felt the challenge in producing their writing. The challenge motivated them to work at their best to get the best. Therefore, the students with high achievement motivation tried at their best to get the best result. From the explanation above, it can be concluded that there was interaction between instructional strategy in teaching writing, BNS strategy and conventional strategy, level of achievement motivation, high and low achievement motivation, toward students' writing achievement.

The third finding in this study showed the result of the first post hoc testing by Tukey test, it was found that the $\mathrm{Q}_{\mathrm{ob}}$ was 10.4. The $\mathrm{Q}$ critical value should be based on three things, they are the level of significant $(\alpha)$, the number of means $(t)$, and the df within that can be seen in ANOVA table (q). For this study the Q critical 
66 | P a g e | Bubble Network System and Achievement Motivation Toward Students' Writing Achievement

value should be $\mathrm{Q}$ with $\mathrm{t}=4$ and $\mathrm{df}=80$. However since the $\mathrm{Q}$ table does not provide 80 degree of freedom, then 60 degree of freedom was used. From the $\mathrm{Q}$ table, the $\mathrm{Q}_{\mathrm{cv}}$ (4:60:0.05) was 3.74 and the $\mathrm{Q}_{\mathrm{cv}}$ (4:60:0.01) was 4.59. This means the $\mathrm{Q}_{\mathrm{ob}}$ was higher than the $\mathrm{Q}_{\mathrm{cv}}$, in both 0.05 and 0.01 level of significance, so $\mathrm{H}_{0}$ was rejected.

Therefore, it can be concluded that there was a significant difference between the students with high achievement motivation taught by using BNS strategy and conventional strategy. The students with high achievement motivation taught by using BNS strategy $(\overline{\mathrm{X}}=81.50)$ showed higher achievement than those with conventional strategy $(\overline{\mathrm{X}}=71.18)$.

The students' achievement motivation is also important factor that could affect the writing achievement. Students who have high achievement motivation are hard workers that always do their best performance to achieve something their lives. He adds that knowing students' achievement motivation has a very essential role to make students gain success in learning a language. It is an urgent variable to be considered by English foreign language. By having high achievement motivation, the students can face the challenges or problems along learning process and solve those problems easily. Having achievement motivation does not mean that individuals were able to do everything and will be as a guide for the students to reach their goal.

Relating to the characteristics of the students having high achievement motivation, the characteristics of BNS strategy have some similarities to the characteristics of students having high achievement motivation. On the other hand, conventional strategy did not provide chance for the students to revise their writing in order to produce writing that is coherent, to know their strengths, progress, and weaknesses when producing their writing. Besides, conventional strategy is teachercentred technique in which the students were not involved actively along teaching and learning process. Those conditions do not support high students achievement motivation in learning to reach their goal. It points indicated that BNS strategy was more appropriate for students having high achievement motivation. It indicated that the high students achievement motivation students were taught by using BNS 
67 | P a g e | Bubble Network System and Achievement Motivation Toward Students' Writing Achievement

strategy, their competence would be better rather than those taught by using conventional strategy.

The fourth finding as the result of the second post hoc testing showed that it was found that the $\mathrm{Q}_{\mathrm{ob}}$ was 0.302 . The $\mathrm{Q}$ critical value should be based on three things, they are the level of significant $(\alpha)$, the number of means $(t)$, and the df within that can be seen in ANOVA table (q). For this study the Q critical value should be df $=80$. However since the $\mathrm{Q}$ table does not provide 80 degree of freedom, then 60 degree of freedom was used. From the $\mathrm{Q}$ table, the $\mathrm{Q}_{\mathrm{cv}}(4 ; 60 ; 0.05)$ was 3.74 and the $\mathrm{Q}_{\mathrm{cv}}(4: 60: 0.01)$ was 4.59. This means the $\mathrm{Q}_{\mathrm{ob}}$ was higher than the $\mathrm{Q}_{\mathrm{cv}}$ in both 0.05 and 0.01 level of significance, so Ho was accepted.

Therefore, it can be concluded that there was no a significant difference between the students with low achievement motivation taught by using BNS strategy and conventional strategy. The students with low achievement motivation taught by using BNS strategy $(\overline{\mathrm{X}}=72.0)$ showed higher achievement than those with conventional strategy $(\overline{\mathrm{X}}=71.72)$.

The students with low achievement motivation were discouraged to have the writing activity. The characteristics of students with low achievement motivation are the opposite of the students with high achievement motivation. They think that the process is not important, but the product is more important. It means that the students with low achievement motivation never tried the best effort to make the best achievement. The students with low achievement motivation need to be stimulated by the interesting teaching technique. Therefore, the BNS strategy had benefit more to the students with low achievement motivation rather than those who were taught by using conventional strategy.

The students said that BNS strategy was the good strategy that could help them to be better writers. The learning process was easy to follow, fun but effective. It guided them to be more independent at the higher level of learning. This technique also helped them to be more responsible to their own learning because they had to be able to construct their own writing, look at the progression of information or ideas in their writing to form coherent writing, and revised their writing to produce 
68 | P a g e | Bubble Network System and Achievement Motivation Toward Students' Writing Achievement

writing that was coherent. The student's centered type of class has helped the teacher to control the class in quite easier way. The activities also were easier to be controlled when teaching and learning process was done.

\section{CONCLUSION, IMPLICATION AND SUGGESTION}

\section{Conclusion}

Based on the research findings of the data analysis the conclusion can be formulated as follows: (1) there is a significant difference on the students' writing achievement between the students taught by using BNS strategy and conventional strategy, the students' English writing achievement taught by using BNS strategy is higher than those taught by using conventional strategy at the eleventh graders of Madrasah Aliyah NW Kotaraja; (2) there is a significant interaction between teaching technique (BNS strategy and conventional strategy) and achievement motivation on the English writing achievement of the eleventh graders of Madrasah Aliyah NW Kotaraja ; (3) there is a significant difference on the students' writing achievement between the students with high achievement motivation taught by using BNS strategy and conventional strategy. The students with high achievement motivation taught by using BNS strategy ( $\overline{\mathrm{X}}=81.50$ ) showed higher achievement than those with conventional strategy ( $\bar{X}=71.18$ ); and (4) there is a significant difference on the students' writing achievement between the students with low achievement motivation taught by using BNS strategy and conventional strategy. The students with low achievement motivation taught by using BNS strategy $(\overline{\mathrm{X}}=72.0)$ showed higher achievement than those with conventional strategy $(\bar{X}=71.72)$.

\section{Implication}

The implication of the research findings have been described are as follows: BNS strategy is an effective strategy to be implemented in English class especially in ESP to improve the students' writing achievement. By implementing BNS strategy, the teacher could stimulate students' creative in learning English. BNS strategy also helps the students to be more active and creative in the learning process. It enables the students to make reflection on their strengths, progress, and weaknesses when 
69 | P a g e | Bubble Network System and Achievement Motivation Toward Students' Writing Achievement

producing their writing learning so that the students can monitor their learning progress. Besides that, the students are active learners in the learning process, rather than recipients of information since they are engaged in learning by doing. The students with high achievement motivation were proven to be more effective if they were taught by using BNS strategy because this technique could challenge the students to give their fullest potential. The students could make reflection on their strengths, progress, and weaknesses when producing their writing learning so that the students call monitor their learning progress.

\section{Suggestions}

It is recommended for the English teacher of senior high school to implement BNS strategy as an alternative strategy in writing class because this strategy has been proven to be effective to improve the students' writing ability. Since achievement motivation has significant role in contributing the senior high school students' writing achievement, the English teacher are expected to know the level of their students' achievement motivation since it will influence the choice in implementing teaching strategy. Besides that, the English teacher should increase the senior high school students' achievement motivation in writing, so that the students can reach their optimum writing.

The other researchers are expected to do the further research according to the effect of BNS strategy and achievement motivation toward other language skills (speaking, listening, and reading) and who want to conduct research to improve the quality of writing achievement, it is recommended to do further research with different writing approach, and characteristics of students. Moreover, it is recommended to research other variables, such as: the location of the school (in city or in village), socio-economic background of the students' parents, etc. 
70 | P a g e | Bubble Network System and Achievement Motivation Toward Students' Writing Achievement

\section{REFERENCES}

Cohen, Laurence, \& keith. (2007). Research Methods in Education. New York, NY 10016.

Dickinson, D. (2001). New Horizon for Learning; Retrieved February 20, 2015 http://www.newhorizon.org/strategies/graphic_toos/dickinson_graphic. html:Internet Journal.

Flower. (1989). A Review of Writing Model Research Based on Cognitive Processes. National Council of Teachers of English.

Gabriel. (1983) Writing the Natural Way: Using Right-Brain Techniques to Release Your Expressive Powers. Los Angeles: J. P. Tarcher, Inc.

Grabe, W and Kaplan, R.B. 1996. Theory and Practice of Writing. London: Longman

http://study.com/academy/lesson/what-is-writing-style-types-examplesquiz.html ; Retrieved April 05, 2015

http://www.englishadvantage.info/lesson/pre-writing-techniques/;

Retrieved March 30, 2015

Hyland, Ken. (2003). Second Language Writing. New York: Cambridge University Press.

Marhaeni, A.A.I.N. 2005. Pengaruh Assessment Portofolio dan Motivasi Berprestasi dalam Belajar Bahasa Inggris Terhadap Kemampuan Menulis dan Bahasa Inggris. Unpublished Disertation: Program Pascasarjana Universitas Negeri Jakarta. 
71 | P a g e | Bubble Network System and Achievement Motivation Toward Students' Writing Achievement

Meade, Vicki. (2010). How to Use Clustering to Jump Start Your Writing. Meade Communication: Retrieved February 20, 2015, from http//meadecomm.com/clustering.html: Internet Journal.

Moedjito. (2014). Basic Statistics for Research in Language Education. STKIP Hamzanwadi Selong.

Scholes, R. Comely, N. (1989). The Practice of Writing, 3rd Ed. New York: St. Martin's.

Tomlinson. S. (1998). English 1301: Retrieved January 20, 2015 from http://www.indiana.edu.L/P/LS2.html.Clustering: Internet journal.

Weigle. (2002). Assessing Writing, Cambridge university press: University of Illinois at Chicago.

White, R. and Arndt, V. (1991). Process Writing. London.: Longman. Journal of Nelta, Vol. 17 No. 1-2.

Williams, James D. 2003. Preparing to teach Writing: research, theory, and practice. 3rd Edition. USA. Lawrence Erlbaum Associates, Inc.

Zenzen.G. Thomas. 2002. Achievement motivation. A Research paper . Iniversity of Wiscosin Stout. on March 15, 2009 